\title{
Artikel Publikasi
}

\section{Efek Jus Buah Jambu Biji Merah (Psidium Guajava L.) Terhadap Kadar HDL Pada Mahasiswa Fakultas Kedokteran Universitas Muhammadiyah Sumatera Utara}

\author{
Nova Anggraini Dalimunte', Shahrul Rahman ${ }^{2}$ \\ ${ }^{1}$ Fakultas Kedokteran Universitas Muhammadiyah Sumatera Utara \\ ${ }^{2}$ Bagian IImu Penyakit Dalam Fakultas Kedokteran Universitas Muhammadiyah Sumatera Utara
}

Email: anggraininova516@gmail.com

\begin{abstract}
Abstrak
Kolesterol ialah suatu zat lemak yang ada di dalam darah, berwarna kekuningan seperti lilin di produksi dalam hati dan sangat penting bagi tubuh. Kolesterol merupakan golongan lipid yang tidak terhidrolisis dan merupakan sterol utama dalam tubuh. Kolesterol yang diproduksi terdiri dari 2 jenis yaitu kolesterol HDL, dan mempunyai sifat antioksidan sehingga dapat mencegah terjadinya oksidasi LDL (High Density Lipoprotein) dan LDL (Low Density Lipoprotein). Berdasarkan latar belakang pada uraian diatas peneliti belum menemukan data-data tentang peningkatan kadar HDL setelah dan sebelum pemberian jus jambu biji merah (Psidium guajava L.) yang diberikan kepada manusia normal, supaya untuk pencegahan terhadap terjadinya penyakit jantung koroner. Sehingga peneliti tertarik meneliti tentang pemberian jus buah jambu biji (Psidium guajava L.) terhadap peningkatan kadar HDL (High Density Lipoprotein) pada manusia normal. Penelitian ini adalah penelitian eksperimental dengan menggunakan desain one group only pret-test post-test design.. Pada uji normalitas Shapiro-Wilk, didapatkan nilai pada data pre-test dan post-test masing-masing adalah 0.705 dan 0.609. Dalam uji normalitas, data dianggap terdistribusi normal apabila didapatkan nilai $p>0.05$. Pada uji $t$-test berpasangan, dapat dilihat antara nilai pretest dan post-test, memiliki nilai $p$ sebesar $0.0005(p<0.05)$. Dari penelitian ini di ternyata dapatkan penurunan kadar HDL pada pemberian jus buah jambu biji merah (Psidium guajava L.) sebanyak $250 \mathrm{ml} /$ hari selama 14 hari.
\end{abstract}

Kata Kunci: HDL, Jus jambu Biji Merah (Psidium guajava L.)

$(\mathrm{cc})$ EY This work is licensed under a Creative Commons Attribution 3.0 License.

\section{PENDAHULUAN}

Kolesterol ialah suatu zat lemak yang ada di dalam darah, berwarna kekuningan seperti lilin di produksi dalam hati dan sangat penting bagi tubuh. Kolesterol merupakan golongan lipid yang tidak terhidrolisis dan merupakan sterol utama dalam tubuh. Darah mengandung kolesterol, dimana $80 \%$ koleterol darah diproduksi tubuh sendiri dan $20 \%$ berasal dari makanan.
Kolesterol yang diproduksi terdiri dari 2 jenis yaitu kolesterol HDL (High Density Lipoprotein) dan LDL (Low Density Lipoprotein). ${ }^{1}$

High Density Lipoprotein (HDL) sering disebut kolesterol baik karena merupakan lipoprotein yang mengangkut lipid dari perifer menuju hepar. HDL memiliki fungsi membersihkan pembuluh darah dari kolesterol LDL yang berlebihan. Hiperkolesterolemia adalah 
tingginya asupan kolesterol memicu peningkatan kadar kolesterol total dan peningkatan LDL akibat tidak terkompensasi oleh HDL untuk dibawa kembali menuju hepar sehingga kadar kolesterol didalam darah melebihi batas normal yang dapat meningkatkan risiko aterosklerosis. $^{2}$

\section{High Density Lipoprotein (HDL)} juga mempunyai sifat antioksidan sehingga dapat mencegah terjadinya oksidasi LDL. HDL yang rendah merupakan faktor risiko yang lebih besar untuk penyakit jantung pada pasien obesitas dibandingkan merokok, total kolesterol, tekanan darah, dan jenis kelamin. Penurunan kadar kolesterol juga sangat penting dalam PJK karena apabila terjadi penurunan kadar kolesterol sebanyak $1 \%$ akan mengurangi risiko PJK sebanyak $2 \%{ }^{3}$ Menurut Riskesdas tahun 2013, terdapat $35,9 \%$ penduduk Indonesia yang memiliki gangguan kolesterol total, 15,9\% memiliki kadar LDL tinggi, 11,9\% memiliki kadar trigliserida tinggi dan 22,9\% memiliki kadar HDL rendah. ${ }^{4}$

Indonesia mempunyai banyak kekayaan akan tumbuhan yang memiliki manfaat sehingga masyarakat menggunakannya sebagai obat herbal untuk mengatasi berbagai macam penyakit, seperti tanaman jambu biji merah. Tanaman tersebut memiliki manfaat untuk pengobatan yaitu daun, buah, akar, dan ranting muda yang memiliki khasiat untuk mengobati macam penyakit. $^{5}$

Jambu biji merah (Psidium guajava $L$.) mengandung sumber vitamin C tertinggi dibandingkan buah lainnya. Fungsi dari vitamin $\mathrm{C}$ dalam metabolisme kolesterol antara lain menurunkan kadar kolesterol dan trigliserida, meningkatkan High Density Lipoprotein-Cholesterol (HDL-C), dan kandungan flavonoid memberikan efek protektif untuk kanker, diabetes melitus, kardiovaskular, stres oksidatif, aterosklerosis, dan hipertensi. ${ }^{6}$

Dari hasil penelitian sebelumnya yang dilakukan Astawan tahun 2013 menyatakan bahwa pemberian jus buah jambu biji merah (Psidium guajava L.) dengan dosis $650 \mathrm{mg} / \mathrm{kgBB}$ tiap $200 \mathrm{ml}$ buah segar sehari 3 kali, 30 menit sebelum makan selama 30 hari hari dapat menurunkan kadar LDL pada pasien dislipidemia. ${ }^{7}$ Dan juga penelitian yang dilakukan oleh Riva Mustika bahwa pemberian jus buah jambu biji merah (Psidium guajava L.) sebanyak $250 \mathrm{ml}$ selama 21 hari dapat meningkatkan kadar kolesterol HDL pada penderita hiperlipidemia. $^{8}$

Berdasarkan latar belakang pada uraian diatas peneliti belum menemukan data-data tentang peningkatan kadar HDL setelah dan sebelum pemberian jus jambu biji merah (Psidium guajava L.) yang diberikan kepada manusia normal, supaya untuk pencegahan terhadap terjadinya penyakit jantung koroner. Sehingga peneliti tertarik meneliti tentang pemberian jus buah jambu biji (Psidium guajava L.) terhadap peningkatan kadar HDL pada manusia normal.

\section{METODE PENELITIAN}

Jenis penelitian ini adalah
penelitian eksperimental dengan
menggunakan desain one group only
pret-test post-test. Penelitian ini
dilakukan di kampus Fakultas
Kedokteran Universitas Muhammadiyah
Sumatera Utara. Proses penelitian ini


dilakukan pada bulan April-Desember 2018.

Pada penelitian ini populasinya adalah Mahasiswa Fakultas Kedokteran Universitas Muhammadiyah Sumatera Utara. Sampel penelitian ini dilakukan pada Mahasiswa Fakultas Kedokteran Universitas Muhammadiyah Sumatera Utara, dengan jumlah total sampel 25 orang. Sampel dipilih melalui kriteria inklusi dan kriteria eksklusi. Kriteria inklusi berupa sampel yang menyetujui informed consent penelitian dan merupakan mahasiswa Fakultas Universitas Muhammadiyah Sumatera Utara, serta kriteria eksklusi berupa subjek yang memiliki riwayat alergi terhadap jambu biji merah, subjek yang menggunakan obat-obatan kolesterol dan subjek yang mempunyai riwayat penyakit lambung.

Metode pengambilan data dalam sampel ini berupa data primer dan data sekunder. Data primer adalah data penelitian yang didapat langsung dari subyek penelitian yang telah diukur kadar HDL sebelum dan sesudah dilakukannya penelitian, sedangkan data sekunder adalah data-data yang mendukung penelitian ini seperti subjek penelitian di Fakultas Kedokteran Universitas Muhammadiyah Sumatera Utara.

Alat yang digunakan pada penelitian ini yaitu spuid $3 \mathrm{cc}$, alkohol swab, sarung tangan steril, spektofotometer, tabung steril, vortex, blander, saringan, takaran air, timbangan dan gelas plastik. Bahan yang digunakan jambu biji merah (Psidium guajava L.) dan air. Langkah-langkah pembuatan jus jambu biji merah yaitu mencuci bersih buah jambu biji merah, mempersiapkan alat dan bahan lainnya lalu memotong buah untuk mudah diblender, kemudian memasukkan buah jambu biji merah sebanyak $150 \mathrm{gr}$ kedalam blender dan ditambah air matang $100 \mathrm{cc}$. Setelah diblender, lalu di masukkan ke dalam gelas plastik.

Pengolahan data penelitian dengan Editing, Coding, Entry, Data Cleaning dan Saving. Urutan uji penelitian yaitu dengan uji normalitas dan uji hipotesa. Pada uji normalitas digunakan uji Shapiro-wilk. Nilai signifikan pada uji normalitas $p>0,05$. Pada analisis setiap kelompok jika ditemukan ada sebarab data yang tidak normal dalam varian berpasangan maka digunakan uji hipotesa alternatif seperti uji Wilcoxon. Tetapi jika data sebaran berdistribusi normal maka dapat dilanjutkan dengan uji hipotesa seperti uji t-test berpasangan (Paired T-test)

\section{HASIL PENELITIAN}

Distribusi mahasiswa Fakultas Kedokteran Universitas Muhammadiyah Sumatera Utara sebanyak 25 orang meliputi jenis kelamin dan usia dapat dilihat pada tabel 1.

Berdasarkan tabel 1 dapat dilihat bahwa responden berjenis kelamin perempuan merupakan yang terbanyak yaitu 16 orang (64\%) dan responden laki-laki $36 \%$. Dapat dilihat bahwa kelompok usia yang paling banyak dijumpai adalah responden berusia 2123 tahun yaitu sebanyak 16 orang (64\%). Disusul oleh responden berusia 18-20 tahun sebanyak 9 orang (36\%). 
Tabel 1. Distribusi Frekuensi Responden Berdasarkan Jenis Kelamin dan usia

\begin{tabular}{ccc}
\hline & $\mathrm{n}$ & $\%$ \\
\hline JenisKelamin & & \\
Perempuan & 16 & $64 \%$ \\
Laki-laki & 9 & $36 \%$ \\
\hline Usia & & \\
$18-20$ & 9 & $36 \%$ \\
$21-23$ & 16 & $64 \%$ \\
\hline
\end{tabular}

Nilai HDL Responden Sebelum dan Sesudah Pemberian Jus Buah Jambu Biji Merah (Psidium guajava L.)

Dari hasil penelitian yang dilakukan, didapatkan nilai HDL sebelum perlakuan (pretest) dan sesudah perlakuan (posttest). Kemudian didapatkan nilai rata-rata HDL subjek penelitian yang terlihat pada tabel 2 .

Tabel 2. Nilai Rata-rata HDL pada Subjek Penelitian

\begin{tabular}{llll} 
& Rata-rata nilai HDL & $n$ & $\mathrm{P}$ \\
\hline Pretest & $58,16 \pm 13,40$ & 25 & 0,000 \\
Postest & $44,2 \pm 9,70$ & 25 & \\
\hline
\end{tabular}

Berdasarkan tabel 2 diatas, terlihat bahwa nilai rata-rata HDL pada subjek penelitian yang didapatkan sebelum perlakuan adalah 58,16 dan setelah perlakuan adalah 44,2, dengan selisih diantaranya 13,96 . Pada uji $t$-test berpasangan, dapat dilihat antara nilai pretest dan post-test, memiliki nilai $p$ sebesar $0.0005(p<0.05)$. Hal ini berarti bahwa, terdapat perbedaan yang bermakna antara pemberian jus buah jambu biji merah (Psidium guajava L.) terhadap kadar HDL mahasiswa Fakultas Kedokteran Universitas Muhammadiyah Sumatera Utara.

\section{PEMBAHASAN}

Berdasarkan tabel 1 dapat dilihat bahwa responden berjenis kelamin perempuan merupakan yang terbanyak berjumlah 16 orang (64\%) dan responden laki-laki berjumlah 9 orang (36\%). Hal ini terjadi karena penelitian ini tidak dirancang dengan baik. Salah satu faktor perancu untuk kadar kolesterol adalah jenis kelamin, maka semestinya distribusi subjek harus setara di antara kedua gender dan penelitian ini sejalan dengan Thaptimthong (2016), dimana subjek penelitian paling banyak ditemukan adalah yang berjenis kelamin perempuan sebanyak $70 \%$ dan yang berjenis kelamin laki-laki sebanyak $30 \%{ }^{7}$ Penemuan demografi jenis kelamin ini sebenarnya tidak memiliki makna tertentu, karena peneliti mencari subjek penelitian dari subjek yang sehat tanpa ada ketentuan penyakit sebelumnya. ${ }^{9}$

Dari penelitian yang dilakukan, didapatkan hasil bahwa jus jambu biji merah (Psidium guajava L.) berpengaruh terhadap kadar HDL. Pemberian ekstrak buah jambu biji (Psidium guajava L.) dengan dosis yang berbeda menunjukkan adanya perbedaan antara kadar HDL sebelum dan sesudah 
perlakuan. Dari hasil gambar 4.1, didapatkan bahwa kadar HDL setelah perlakuan lebih rendah dibandingkan kadar HDL sebelum perlakuan, namun penurunan kadar HDL tersebut masih dalam batas normal. Hal ini sesuai dengan penelitian yang dilakukan Ivan, bahwa pemberian terapi jus buah jambu biji dosis $650 \mathrm{mg} / \mathrm{kg}$ BB dalam bentuk sediaan $200 \mathrm{ml}, 30$ menit sebelum makan selama 30 hari dapat menurunkan kadar HDL. ${ }^{9}$

Adanya penurunan kadar HDL dalam darah antara sebelum dan setelah perlakuan disebabkan oleh peneliti yang tidak melakukan pengontrolan terhadap konsumsi makanan pada subjek penelitian. Sesuai dengan penelitian yang dilakukan oleh Riva dkk, bahwa adanya perbedaan kadar HDL dalam darah setelah diberikan jus buah jambu biji merah (Psidium Guajava L.) dikarenakan asupan lemak terutama lemak jenuh pada subjek penelitian yang tidak dikontrol. ${ }^{8}$ Pengaruh asam lemak jenuh pada metabolisme lipoprotein mampu menghambat kerja dari enzim lechtin cholesterol acytransferase (LCAT) yang berperan mengeluarkan kolesterol dari lipoprotein dan jaringan. Hal ini mengakibatkan HDL tidak terbentuk dan kolesterol yang berlebihan tidak dapat diangkat kembali ke hati sehingga terjadi penurunan kadar HDL dan HDL tidak berfungsi dengan baik. ${ }^{10}$

Selain hal diatas, asupan karbohidrat pada subjek penelitian yang tidak dikontrol juga dapat mempengaruhi penurunan kadar HDL dalam darah. Hal ini sesuai dengan penelitian yang dilakukan oleh Dwi, bahwa tingginya karbohidrat didalam tubuh akan meningkatkan laju lipogenesis dan esterifikasi asam lemak sehingga menyebabkan penurunan kadar HDL. ${ }^{11}$ Dan penelitian yang dilakukan oleh Shah, asupan pola makan dan banyaknya makanan yang mengandung tinggi karbohidrat dapat menyebabkan penurunan kadar HDL akibat kelainan metabolisme lipoprotein. ${ }^{13}$ Sehingga, kemungkinan hal-hal tersebut dapat mempengaruhi kadar HDL dalam darah pada penelitian ini.

Dari hasil penelitian peneliti setelah pemberian jus buah jambu biji merah terjadi penurunan kadar HDL hal ini juga sesuai dengan penelitian yang dilakukan oleh Priyanti, menyatakan bahwa terjadi peningkatan kadar kolesterol total, kadar LDL, kadar Trigliserida dan penurunan HDL dengan menggunakan ekstrak buah jambu biji merah (Psidium guajava L.). Hal ini disebabkan dosis yang terlalu kecil, sehingga kandungan pektin dalam ekstrak tidak dapat mengikat semua kolestreol dan lemak dalam tubuh. ${ }^{12}$

Dan dari hasil penelitian terjadi penurunan kadar HDL hal ini sesuai dengan yang dilakukan oleh Rahmad, Mohd Fadzelly Abu Bakar dan Zaridah Hambali (2006) dapat disimpulkan bahwa pemberian jus jambu biji merah $400 \mathrm{mg}$ yang dilakukan pada pria normal dengan desain pre dan post yang akan memberikan hasil dimana dapat meningkatkan kadar antioksidan dan menurunkan kadar HDL, sedangkan peneliti tidak mengukur kadar antioksidan $^{13}$ Menurut penelitian yang dilakukan oleh Kelishadi, dengan studi case-control dengan memperlihatkan bahwa seseorang yang terkena paparan polusi di aderah perkotaan mempunyai keseimbangan lemak darah dengan rendahnya kadar HDL, hal ini sangat memiliki perbedaan dengan kelompok 
kontrol yang tidak sering terpapar polusi udara. $^{14}$

Adapun penelitian yang berbeda dengan hasil penelitian ini yang menunjukkan peningkatan kadar HDL adalah penelitian Singh dkk. Pada penelitian Singh dkk, dijumpai peningkatan kadar HDL setelah pemberian jus buah jambu biji merah yang diberikan kepada penderita hiperlipidemia dengan hipertensi ${ }^{15}$

\section{KESIMPULAN}

Dari penelitian ini di ternyata dapatkan penurunan kadar HDL pada pemberian jus buah jambu biji merah (Psidium guajava L.) sebanyak 250 $\mathrm{ml} /$ hari selama 14 hari.

\section{REFERENSI}

1. Septianggi FN. Hubungan Asupan Lemak dan Asupan Kolesterol dengan Kadar Kolesterol Total pada Penderita Jantung Koroner Rawat Jalan di RSUD Tugurejo. J Gizi Univ Muhammadiyah Semarang; 2013 hal.13-20.

2. Anwar, T. Bahari. Dislipidemia sebagai Faktor Resiko Penyakit Jantung Koroner. Medan: FK USU Medan. 2013.

3. Jani Deepti K. GS. Ameliorative effect of Raphanus sativus and Cassia angustifolia in Experimentally Induced Hyperlipidemia and Cardiovascular Risk Reduction. J Pharm Tech Res; 2017; 273-279.

4. Carter M. Low hdl cholesterol the biggest modifiable risk for cardiovascular disease in patients with hiv. 25 february 2011.

5. Zulaekah S, Rahmawati AC, Rahmawaty S. Aktivitas Fisik dn Rasio Kolesterol (HDL) pada Penderita Penyakit Jantung Koroner di Poliklinik Jantung RSUD Dr Moewardi Surakarta. Jurnal Kesehatan. 2016; vol;2(1):11-18.
6. Oktora L, Kumala R, Pengajar S, Studi P, Universitas F. Pemanfaatan Obat Tradisional Dan Keamanannya. Maj IImu Kefarmasian. 2010; III(1):1-7.

7. Astawan IWS. Efek Jus Buah Jambu biji (Psidium Guajava L.) pada Penderita Dislipidemia. Calyptra: Jurnal IImiah Mahasiswa Universitas Surabaya. 2013; 2(1): 6.

8. Riva Mustika Anugrah, Kusmiyati Tjahjon, Martha Irende Kartasurya. Jus Buah Jambu Biji Merah (Psidium guajava L.) Dapat Menurunkan Skor Atherogenic Index of Plasma. Departemen IImu Gizi Fakultas Kedokteran Universitas Diponegoro, Semarang. 2017.

9. Dwi RSN. Hubungan asupan karbohidrat dan lemak dengan kadar profil lipid pada pasien jantung koroner rawat jalan diRSUD Dr. Moewardi Surakarta. Naskah Publikasi Universitas Muhamddiyah Surakarta. 2015.

10. Shah S,S, Gaurang B,S. Satbeer D, $S$. Effecy of piperine in the regulation of Obesity-Induced Dyslipidemia in High-Fat Diet Rats.Indian Journal of Pharmacology.2011.

11. Priyanti, L. Pengaruh Pemberian Ekstrak Daun Salam (eugenia polyantha) Terhadap Kadar hdl, Idl, dan Kolesterol Total Serum tikusjantan galur wistar hiperlipidemia, semarang :universitas diponegoro. 2011.

12. Rahmad, Asmah, Mohd Fadzelly Abu Bakar dan Zarida Hambali. The Effect of Guajava (Psidium guava L.) consumption on total antioxidant and lipid profile in normal male. 2006.

13. Kelishadi R, Poursafa P, Health C. Impact of climate change and air pollution on dyslipidemia and the components of metabolic syndrome. In Dyslipidemia-From Prevention to Treatment. InTech. 2008.

14. Singh RB, Rastogi SS, Singh R. Effects of guava intake on serum 
total and high-density lipoprotein cholesterol levels and on systemic blood pressure.Am J Cardiol. 2015;70:1287-91.

15. Novita Carolia dan Ulima Mazaya Ghaisani. Psidium guajava sebagai antihiperlipidemia dan antihipertensi, lampung: universitas lampung. 2016. 